\title{
Pryfiognomifae \\ $\Re \mathfrak{i} \mathfrak{i} \mathfrak{i}$.
}

Boran

ein phyfiognomifd

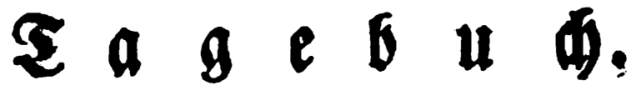

Seftweib" berausgegeben.

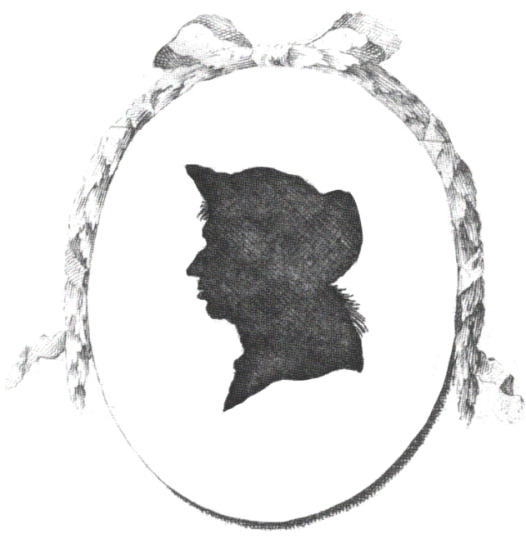

\section{A t ten 6 arg}

im bet Stidterfaen \$udbanolung, 2788. 
